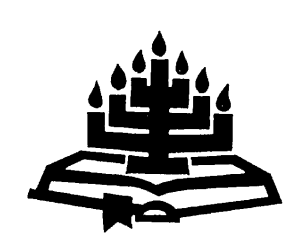

\title{
Violence in post-apartheid South Africa and the role of church and theology ${ }^{1}$
}

\author{
C.F.C. Coetzee \\ School of Ecclesiastical Studies \\ Potchefstroom Campus \\ North-West University \\ POTCHEFSTROOM \\ E-mail:kwscfcc@puknet.puk.ac.za
}

\begin{abstract}
Violence in post-apartheid South Africa and the role of church and theology

South Africa is known as one of the most violent countries in the world. Since the seventeenth century, violence has been part of our history. Violence also played a significant role during the years of apartheid and the revolutionary struggle against apartheid. It was widely expected that violence would decrease in a post-apartheid democratic South Africa, but on the contrary, violence has increased in most cases. Even the TRC did not succeed in its goal to achieve reconciliation. In this paper it is argued that theology and the church have a great and significant role to play. Churches and church leaders who supported revolutionary violence against the apartheid system on Biblical "grounds", should confess their unbiblical hermeneutical approach and reject the option of violence. The church also has a calling in the education of young people, the pastoral care of criminals and victims, in proclaiming the true Gospel to the government and in creating an ethos of human rights.
\end{abstract}

\section{Opsomming}

Geweld in Suid-Afrika ná apartheid en die rol van kerk en teologie

Suid-Afrika staan bekend as een van die mees gewelddadige lande van die wêreld. Sedert die sewentiende eeu was geweld

1 Reworked version of a paper delivered at the international conference of IRTI held at Kinashi, Indonesia, 8 to 13 July 2003. 
deel van ons geskiedenis. Dit het ook 'n beslissende rol gespeel in die stryd teen apartheid. Daarom is allerweë verwag dat geweld sou afneem in die demokratiese nuwe Suid-Afrika. Die teendeel het in die meeste opsigte gebeur en geweld neem steeds toe. Selfs die Waarheids- en Versoeningskommissie kon nie daarin slaag om versoening te bewerkstellig nie. In hierdie artikel word gefokus op die rol van die teologie en die kerk in die bekamping van (veral) polities-geïnspireerde geweld. Die kerke en teoloë wat die Bevrydingsteologie verkondig het en hulle geskaar het aan die kant van die revolusie teen apartheid, behoort skuld te bely en te erken dat hulle met 'n onskriftuurlike hermeneutiek gewerk het. Die kerk het ook 'n roeping en verantwoordelikheid ten opsigte van die opvoeding van die jeug, die pastorale begeleiding van slagoffers van geweld en misdadigers, die Skriftuurlike getuienis teenoor die owerheid en die bevordering van 'n etos van menseregte.

\section{Introduction}

Violence is a world-wide and most complicated phenomenon. In most cases violence can also be regarded as sin. The importance of this theme can therefore not be over-emphasised. The testimony and deeds of the Church of Christ as well as the doctrine of sound Scriptural theology are urgently needed in a time of increasing violence.

It must further be kept in mind that the subject of violence is so extensive that it can hardly be overseen. Floor (1990:55) uses the following definition of violence: "... an unnecessary, excessive, hurtful and unlawful use of force". Referring to Ballard, he further distinguishes at least five forms of violence: ideological, structural, institutional, criminal and pathological violence (Floor, 1990:55). Van Wyk (1991:89-96) distinguishes among the following forms of violence: psychological violence, structural violence, revolutionary violence, rebellious violence, police violence and military violence. It is the aim of this article to focus on the so-called structural violence and counter-violence related to the political and social revolution which took place in South Africa (also known as the liberation struggle or the struggle against apartheid) and led to a democratic new South Africa in 1994. In the same context, attention will be given to the ongoing and escalating violence and new forms of structural violence in post-apartheid South Africa, before focusing on the role that the church and theology can and should play in combatting violence. 
Attention will therefore not be given to other forms of violence, such as family violence, various forms of sexual violence, crime, etc. that are not directly related to the political situation, although in many cases it is very difficult to make a clear distinction (Van Niekerk, 1985:91, 92).

\section{Historical oversight and background}

South Africa is known as one of the most violent countries of the world. More than eighty murders are committed every day. On a list published by Interpol in 1995, South Africa was third out of 96 countries as far as murders are concerned, second in the case of sexual violence and first as far as rape is concerned (Vorster, 2003:4). The fact that the South African Government placed a moratorium on the publication of statistics, makes it difficult to get a clear picture. As a result, the available statistics from other sources are frequently outdated. The following statistics may, however, give some idea of the extent of violence (Claasen, 1999:189): The ratio per 100000 of the population for murder in 1998 was 58,5, for attempted murder 69,2 and for robbery with aggravating circumstances, 207,6.

From 1991 to 1999 the increase in farm attacks was $96 \%$ on average. While murders in South Africa decreased from 1994 to 1999, farm murders increased. From January 1997 to January 1998, there was an average of 36 farm attacks per month that escalated from February 1998 to February 1999 to an average of 67 farm attacks per month. This represents an increase of $86,1 \%$ on average per month, and in February 1998 to March 1998 farm attacks increased by $97,1 \%$ compared to the rate for January 1998. It is evident that 870 murders have been committed during 4624 farm attacks from 1991 to 1999 (Action Stop Farm Attacks, 2001:2).

(This number has since increased to approximately 1500 .)

It must be noted, however, that the history of South Africa has been characterised by the occurrence of violence to a greater or lesser extent since the middle of the seventeenth century and even earlier. Between 1770 and 1775 the so-called "free burghers" met the migrating Bantu on the expanding eastern borders of the Cape of Good Hope. The subsequent clashes and confrontation between the two totally different cultures resulted in border wars and retaliation (Action Stop Farm Attacks, 2001:5). This was one of the reasons for the "Groot Trek". On their way north the Trekkers met with black-onblack violence between the Zulu and Matabele inter alia, but the 
Trekkers themselves were attacked and had to defend themselves in bloody battles like that of "Vegkop" (against the Basutu) and "Bloodriver" (against the Zulu). During the period of colonisation by Great Britain (from 1805 to 1910) the demographic and geographic face of the subcontinent changed. The demarcation of land and the movement of people were forced onto black communities with their African communalistic culture and spiritual bond with the land, as well as onto Europeans with their concept of free enterprise and puritanical work ethic and culture. The Afrikaner, as well as the Bantu peoples experienced the imperialistic colonisation of the land as a form of oppression (Action Stop Farm Attacks, 2001:5). The two Boer republics, the Orange Free State and the Transvaal, lost their sovereignty to Great Britain after the second Anglo-Boer war of 1899 to 1902, during which approximately 26000 women and children died in concentration camps. With the Peace Accord of Vereeniging of 31 May 1902 both Republics became integrated parts of colonised South Africa.

With the realisation of the Union of South Africa in 1910, the struggle continued between the black majority and the white minority that formed the Government. The African National Congress (ANC) was founded in 1912. In 1948 the National Party came into power after using the slogan of "apartheid" in the election campaign. Since then the struggle and "structural violence" intensified between the apartheid system with its discriminatory laws and the "counter violence" of the ANC and its allies, Cosatu, the South African Communist Party (SACP) and the South African Council of Churches (SACC). The government regarded the "revolution" and its methods as the reason for implementing military and other measures to curb the revolution, while they were looking for a political solution in the policy of "separate development". The ANC and its allies on the other hand, perceived the system of "injustice" and the "illegitimacy" of the government as giving them the right to implement revolutionary methods such as actions of civil disobedience, sabotage and other violent means to bring apartheid to an end. Violence was seen by many as "the religion of the apartheid system" (Smith, 1999:52).

The result of the struggle was that the respective parties were forced to the negotiating table and this process led to the creation of the new democratic South Africa. In 1994 the South African Constitutional State came into being with the aim to entrench the highest authority of the law in the Constitution and to bind the judiciary process to the Bill of Rights in order to prevent the misuse of power by the government as far as possible (Vorster, 2003:112). 
Within the context of this article it is important to emphasise the role of certain churches and church organisations as well as prominent church leaders in the struggle against apartheid. The struggle can be mainly associated with the following groups: The ANC and its allies, Cosatu, the SACP and the SACC. Tutu (1983:127) comments thus on the role of the SACC and the relationship with the government:

Apartheid is as evil and as vicious as Nazism and Communism and the Government will fail completely for it is ranging itself on the side of evil, injustice and oppression. The Government are not God, they are just ordinary human beings who very soon like other tyrants before them - will bite the dust when they take on the SACC they must know that they are taking on the Church of God and those who have done so in the past, the Neros, the Hitlers, the Amins of this world, have ended up ... as the flotsam and jetsam of history.

Wallis and Hollyday $(1989: 7,8)$ emphasise the following:

The youth division of the SACC is deeply involved in the black townships. The militant township youth, who provide so much energy to the struggle against apartheid, are finding new hope in the churches, mainly because of the leadership of the people like Boesak and Tutu.

The leaders of the SACC expressed their viewpoints on the issue of violence clearly on several occasions. At the funeral of Steve Biko, Tutu $(1983: 14,15)$ said:

I have seen too much violence in other parts of the World to talk glibly about it, but I do want to issue a serious warning, a warning I am distressed to have to make, and it is this: When people are desperate then they will use desperate methods. Please, please for God's sake listen to us whilst there is just a possibility of reasonably peaceful change.

It is clear that although Tutu pleaded for a peaceful solution, he never totally rejected the option of violence. On the contrary, he said: "If sanctions should fail, there is no other way but to fight" (Villa-Vicencio, 1990:50). On his relationship with the ANC he (Tutu, 1989:37, 38) said:

I support the ANC ... I don't support the methods that they are using. But I stick to them. They are my brothers; they are my sisters; they are my friends; they are my fathers; they are my mothers. How can I repudiate them? 
In a sermon on the first book of Kings, chapter 19, Allan Boesak $(1989: 30,31)$ urged the church to become more involved in the revolution:

I call upon the church, my brothers and my sisters. We are entering now a new phase of persecution of the church in this country. But there can be no turning back. Those of you who have decided to follow Jesus Christ must follow Jesus Christ now, even into the streets of this country and into the face of the casspirs, and the guns, and the water cannons and the tear gas ... don't turn back now because this monster has reared its ugly head once again. That is not what we are here for.

These quotations clearly illustrate that Boesak places the blame for the violence before the door of the government and that "counter violence" is therefore justified. Boesak's utilisation and application of Scripture also clearly indicate that he adheres to the methods of the liberation theology. It is also important to note that Boesak has been influenced by the theology of someone like Dietrich Bonhoeffer (Boesak, 1987:9), as was Beyers Naudé.

The same viewpoint is expressed by Frank Chikane (1989:76, 77):

The attacks on the church by the state have, in fact, mobilized more Christians ... The government will have to face a massive upsurge of the members of the churches against the apartheid system. Anything they do besides going to the negotiating table is going to make the situation worse ... I think we've entered the worst period, and it's going to become much worse than it is at the present moment. I suspect that as the congregations go to the streets, the system is going to be more and more brutal.

It is significant to note that church leaders like Chikane and others have since taken up senior political positions in a new South Africa. It would probably have been the case with Boesak as well, had he not been found guilty and convicted on charges of fraud and corruption.

\section{Violence in post-apartheid South Africa}

It has been widely expected that in a new democratic South Africa the violence-related political power struggle would come to an end. White political leaders indicated this assumption as a main reason for agreeing on a negotiated settlement with the ANC. Much was expected from the new Constitution and the Bill of Rights. 
Furthermore, the Truth and Reconciliation Commission (TRC) was established. This commission came into being in an effort to heal the nation and to deal with the past. It was believed that the stories from the past had to be narrated before the past could be buried (Du Toit, 1999:15). As far as the mandate of the TRC was concerned, the Commission was conceived as part of the bridge-building process designed to help lead the nation away from a deeply divided past to a future founded on the recognition of human rights and democracy (TRC, 1998: Vol 1:48).

One of the main tasks of the Commission was to uncover as much as possible of the truth about past gross violations of human rights - a difficult and often very unpleasant task. The Commission was founded, however, in the belief that this task was necessary for the promotion of reconciliation and national unity (TRC, 1998, Vol. 1:49).

The TRC was not a permanent institution, but was meant to facilitate the launching of a new era (Du Toit, 2000:125). The mandate, significantly, was formulated in terms of the need to address gross human rights violations - "the killing, attempted killing, abduction, (and) severe ill-treatment or torture" of past political conflicts (Du Toit, 2000:127). "This reflected a specific moral and political diagnosis of the transition from apartheid" (Du Toit, 2000:127). Archbishop Desmond Tutu was appointed as chairman of the TRC and a number of other church leaders, most of whom were actively involved in the anti-apartheid struggle, were appointed as officers. Du Toit $(1999: 15,16)$ is of the opinion that the

... process has been one of the most successful of its kind in the world. Healing has taken place and many families have eventually come to know what happened to their loved ones ... For many who still believed that apartheid was good or had some good in it, it became more difficult to continue justifying apartheid ... The charisma and atoning attitude of bishop Tutu played a pivotal role and set an example for many to follow. The TRC process convinced most South Africans of the evil of the past and of the necessity of reparation.

As far as the involvement of faith communities in the years before 1994 is concerned, the Commission came to the following conclusion (TRC, 1998. Vol. 5: 252):

It is the finding of the Commission that religious proselytizing and religious-based nationalism have not only sown the seeds of inter-religious suspicion, distrust and strife, but they have also contributed directly to religiously inspired conflict. Religious 
communities must take responsibility for the actions of their followers in this regard.

Nevertheless, a tragic facet of the new South Africa is that the violence has not decreased or stopped. On the contrary, to a certain extent it has increased dramatically as was indicated by statistics previously mentioned. Apart from the violence already referred to, it should also be noted that violence between opposing black political groups, such as the ANC and UDM in Kwazulu Natal still continues (Reitsema, 1998:26, 27). Members of the so-called "Boeremag" are at the moment standing trial for the alleged planning of violently overthrowing the government. Most of the accused probably belong to the religious group or cult called the Israel Vision.

Apart from the many forms of physical violence, various aspects of the ANC government's policy are experienced by many people and minority groups as new forms of structural violence that have replaced the structural violence of apartheid. In this regard the following serves as examples: the affirmative action policy and regulations, the proposed law regarding religious education and the practising of religion in public schools, the dictatorial way in which tertiary institutions such as the Potchefstroom University for Christian Higher Education have been forced to merge and in the process lost their name, and maybe also their specific character and ethos, etc.

Roodt (2003:3) stresses the role government can play in either continuing or ending structural violence against ethnical minority groups. Many reasons can be given for the ongoing and escalating violence. A number of the most obvious and important ones includes the following:

- Increasing poverty and unemployment.

- The inability of the government to maintain law and order. In many cases members of the police force and the military have themselves been involved in actions of crime, violence, corruption and fraud.

- Some people are of the opinion that the government is in a certain sense not totally committed to make an end to violence. It took for instance a few years to release the report on farm murders. When it was finally handed over to the minister of Safety and Security, Mr. Charles Nqakula, on 20 August 2003, it was returned to the Committee, because the minister responsible for safety was "not satisfied" with some of the findings (Louw, 
2003c:1). In reaction to this, agricultural organisations and political parties urged the government to release the report immediately (Louw, 2003d:4) and expressed their concern that politicians would tamper with the report (Louw, 2003c:1). Meanwhile the report was leaked to the newspaper Beeld that in turn reported that racist hate was the cause of the intense and brutal violence in farm attacks, although the motive in most cases was theft and robbery (Louw, 2003d:1).

- Some people do not regard violence as sin, and justifies violence from the same ideological and theological viewpoint expressed by people like Boesak, Tutu, Villa-Vicencio and others during the apartheid struggle, while ongoing practices of apartheid are still frequently blamed for the continuing violence.

- Racism. The actions of members of the "Boeremag" definitely contribute to the fuelling of racism, while many people see the ongoing attacks on and killing of farmers as a form of genocide (Louw, 2003a:5; 2003b:2; Action Stop Farm Attacks, 2001:26).

- Although he evaluates the TRC process very positively, Du Toit $(1996: 16)$ agrees that it is debatable whether the TRC has succeeded in fostering reconciliation.

It cannot be denied that the stories that were disclosed at the TRC hearings aroused intense feelings of aggression which play a role in the high crime rate. It is ironic that, while past atrocities were being uncovered in TRC hearings, the following chapters of continuing atrocities were written in daily crime activities (Du Toit, 1999:16).

In the end the TRC was an instrument in the hands of the "winner" of the struggle and focused its attention wrongly mainly on the crimes of apartheid. The TRC was a statutory body, approved by Parliament. It, however, never really functioned in that way due to the fact that it was only a quasi-judicial body with the emphasis on ethical matters in the hearings during the first part of the process. Law and ethics were mixed.

Subsequently, as the quasi-judicial and adversarial procedures of the amnesty hearings began to take center stage, the TRC's practice shifted from acknowledging truth as a means of reconciliation to the imperatives of observing the procedural rights of those implicated by the disclosures and allegations in the course of this process. At other hearings, too, lawyers and legal procedures played an increasingly prominent role. Finally, with the publication of the TRC's Final Report, it emerged that in the Commission's own view the victim's 
hearings had been only one phase of the process and had increasingly been subordinated to the methodology of systematic data processing and the corroboration of statements as a basis for the objective of making victim and perpetrator findings, instead of achieving closure to the TRC process, this finding served to bring the Commission into confrontation with the ANC (Du Toit, 2000:131).

- Vorster (2003:114) emphasizes the lack of an ethos of human rights among citizens.

\section{The role of church and theology}

During the years before 1994 especially the predominantly white Afrikaans-speaking denominations pleaded for action against violence (Anon., 1990:1, 2; Anon., 1991a, Anon., 1991b:1; Anon., 1993a:1; Anon., 1993b:1; Anon., 1993c:27) while most of the black and English-speaking denominations sided with the revolution in the struggle against apartheid. It is significant, however, that since 1994 the different denominations have almost been silent on the issue, to such an extent that the question has been asked: Where have all the prophets gone? (Mayson, 1999:55; Pieterse, 1999:32). Mayson is of the opinion that religion does not know which way to go. It has not found its role in the new South Africa (Mayson, 1999:58). In its final report, the TRC also emphasised the role of churches in the process of reconciliation and stated inter alia the following (TRC, 1998. Vol. 5:316): "Faith communities enjoy a unique and privileged position in South African society. They are widely respected and have far-reaching moral influence. As such, they should play a key role in healing and reconciliation initiatives". It is therefore of utmost importance that the role of church and theology be clearly defined. In conclusion thus a few remarks in this regard.

\subsection{The role of theology}

As far as theology is concerned, theologians who and denominations that proclaim the importance of liberation theology, will have to make a radical paradigm shift. It was clearly indicated that in the years before 1994 they did not totally reject actions like illegal civil disobedience, sabotage and even other forms of violence. On the contrary, they were part of the struggle and urged their followers and members to take part actively in the struggle; to see this participation as a calling, based on a specific way and method of interpreting the Bible. The question thus remains what the contents of their teaching and sermons will be now that the struggle is supposed to be over. In this context, Pieterse $(1999: 82,83)$ makes the following statement: 
Since the sixties until the change in 1994, the prophetic church in South Africa, directed by South African liberation theology, has had an enormous influence on people, here and overseas, so much so that the previous government eventually had to fully acknowledge this ... The church spoke with a powerful and fearless voice against apartheid, the state theology and the church theology of the eighties (as quoted in Kairos Document, 1986).

Pieterse (1999:83) subsequently poses the following question: "How is it possible that the ecumenical prophetic church has suddenly become powerless and apparently can make no contribution to the solution of the country's enormous social and moral problems?" (Pieterse, 1999:83).

A new theology will have to entail a new (or rather true Biblical) hermeneutical approach. In this regard the following quotation is relevant:

The hermeneutical model of the so-called alternative theology works with two principal presuppositions: Biblical exegesis and as a result, theology, has to be contextual. This means that we have to interpret and to apply the Bible in terms of the historical situation of today. Secondly the Kingdom of God has to be seen as being fully for the present reality. 'To place oneself in the perspective of the Kingdom means to participate in the struggle for liberation of those oppressed by others' [Gutierrez, as quoted by Floor - CFCC]. But the proper hermeneutical principle for interpreting the Bible on the issue of violence too is the method the Bible itself offers to its readers. We have to accept that the Scriptures is the Word of God from beginning to end, all-inclusive and in its entirety. The most important argument of all is that we should believe in the authority of the Bible because the Scripture itself claims that authority ... Our exegesis has to be contextual, but this has to be the context of the Bible itself. It is hermeneutically erroneous to believe that the Bible has to be viewed from the existing socio-political situation. It is not permitted to use a modern context as an hermeneutical key to interpret a text of the Bible (Floor, 1990:58).

It can surely be expected from the above-mentioned theologians and churches to admit and confess (as it was expected of the white Afrikaans-speaking denominitions to confess their approval of apartheid on Biblical grounds) that they used the wrong (unbiblical) hermeneutical key in interpreting the Bible. Consequently they misled people and did not proclaim the true Gospel of Jesus Christ. 
The true Gospel is that "... the church of the New Testament was never involved in violence. The answer to the church of Jesus Christ about violence is the Word of God, prayer, Christian charity and from God's side the answer to prayer is the Holy Spirit" (Floor, 1990:64). The church of Christ is called to promote peace in the Biblical sense of the word since peace belongs to the essence and structure of the church (Van Wyk, 1991:97). The justification of violence by the church is therefore not admissible and the support by the church of organisations that promote violence is unscriptural (Van Wyk, 1991:97).

It must therefore be taught and preached in no uncertain terms that violence in the context in which the term is used in this article, is sin and can not be justified from a Biblical perspective.

If we keep in mind that those denominitions (individually and as part of the SACC) that supported the struggle, represent by far the majority of the population, we can imagine what effect the true Biblical message could have.

\subsection{The role of the church}

It is the calling of the church of Jesus Christ to proclaim the true Gospel to all people and under all circumstances. The real message of the Gospel has remained the same through all times. This is the message of the only true God, who is the God of peace (2 Cor. 13:11) and the Gospel of peace (Eph. 2:17). The Holy Spirit works the true faith in Jesus Christ as the only Mediator and Saviour, through the preaching of this Gospel (Rom. 10:17). Through the same gospel the true believers are equipped for their task and calling in the church but also in the Kingdom of God (Eph. 4:11, 12).

The church fulfils (or ought to fulfil) this calling primarily on grassroots level, in the local congregation where the true characteristics of the church are revealed (Article 29 of the Belgic Confession). The church does this in the firm conviction that it is only the Holy Spirit who can change the heart of man.

In the same context, the calling of the church regarding the following aspects should be emphasised:

- The catechesis of young people to equip them with the sound Biblical doctrine and in so doing foster their growth in faith and holiness. 
- The development of "traditional family values" which is an absolute condition for a healthy community (Petersen, 1999:116).

- Pastoral care for all its members and especially for victims of violence (Van Niekerk, 1985:90-92).

However, the church (the local church, but also all the local churches together) has a calling in the world. In this regard research has indicated that the privatisation of religion finally disempowers the church to play a role in public life (Pieterse, 1999:94). Within the context of violence, Van Niekerk (1985:109-110) stresses the following:

Political violence will only be allayed when, individually and collectively, change works through to the social-structural context. Towards this comprehensive 'change' through reconciliation the pastoral work of the church is directed ... Only in this way can the shalom of God and his already proclaimed 'Peace on earth' acquire tangible shape in Christ.

The role of the church in bringing about reconciliation is also emphasised by Petersen (1999:110), Van Wyk (1991:99) and Helmick $(1999: 138,139)$. In this regard it is crucial to remember that real reconciliation between people and opposing groups must stem from true Biblical reconciliation with God through Christ.

In a practical way churches can mediate and facilitate among groups by founding centres for counselling. Church members can also cooperate with the police force and the military in various ways (encouraging them with the Gospel, counselling, accompanying them when they patrol the streets and spread the Gospel through pamphlets, etc). The Gospel must be proclaimed to prisoners and must be followed up when they are released.

Du Toit emphasises the role the church could play in promoting what he calls the "common good" in South Africa. "Building a new South Africa cannot be done without religious support. Churches and religious groups must be mobilized to promote the values needed to strengthen a common good" (Du Toit, 1999:31). In this regard he refers to Jeremiah 29:7: "But seek the welfare of the city where I have sent you into exile, and pray to the Lord on its behalf, for in its welfare you will find your welfare."

Vorster (2003:114) sees a definite role for the church in establishing and promoting an ethos of human rights in South Africa. This role can be fulfilled in various ways (intervention, preaching, diaconal 
and pastoral care, church meetings, ecumenical bodies, etc.) (Vorster, 2003:464-474).

A very important and indispensable role of the church is that of being witness to remind (and if necessary reprimand) and encourage the government in the fulfilment of its God-given task for which it is appointed, that is to punish the evil-doers and protect those who do well (Rom. 13; cf. Belgic Confession, Article 36).

In final instance, the church must fulfil its calling by proclaiming and serving the Kingdom of God, the Kingdom where Christ reigns as the Prince of Peace (Is. 9:6), the Kingdom which implies righteousness, peace and joy in the Holy Spirit (Rom. 14:17).

\section{List of references}

ACTION STOP FARM ATTACKS. 2001. A memorandum on farm attacks and the implications thereof to commercial agriculture and food production in South Africa. Presented to the Executive Committee of The action stop farm attacks, February.

ANON. 1990. NG kerklui bespreek geweld met President. Die Kerkbode, 145(11):1, 2.

ANON. 1991a. Gebruik van en uitlok tot geweld is onaanvaarbaar. Die Kerkbode, 148(8):12.

ANON. 1991b. Kerk, owerheid en geweld. Die Hervormer, 84(5):1.

ANON. 1993a. Drie Afrikaanse kerke vra vrede, nie geweld nie. Die Kerkbode, 152(21):1.

ANON. 1993b. Kritieke week: Kerk praat oor geweld. Die Kerkbode, 152(19):1.

ANON. 1993c. Verklaring van drie Afrikaanse kerke insake geweld. Die Kerkblad, 27, Mei 19.

BOESAK, A.A. 1987. Comfort and protest: Reflections on the apocalypse of John of Patmos. Edinburgh: Andres.

BOESAK, A.A. 1989. Your days are over! A sermon by Allan Boesak. (In Wallis, J. \& Hollyday, J. Crucible of fire: The church confronts apartheid. Maryknoll: Orbis Books \& Sojourners. p. 30-33.)

CHIKANE, F. 1989. Through the cross: The South African church's painful path to victory: An interview with Frank Chikane. (In Wallis, J. \& Hollyday, J. Crucible of fire: The church confronts apartheid. Maryknoll: Orbis Books \& Sojourners. p. 176, 177.)

CLAASEN, J.J. 1999. Statistics, perspectives and perceptions: interpreting crime and violence in South Africa. (In Du Toit, C.W., ed. Violence, truth and prophetic silence: Religion and the quest for a South African common good. A compilation of papers presented at the twenty-third symposium of the Research Institute for Theology and Religion (Unisa) held at the University of South Africa. Pretoria. 3-4 June. p. 178-190.)

DU TOIT, A. 2000. The moral foundation of the South African TRC: Truth as acknowledgement and justice as recognition. (In Rotberg, R.I. \& Thompson, D., eds. Truth v. Justice. The morality of truth commissions. Princeton: Princeton University Press. p. 122-140.) 
DU TOIT, C.W. 1999. Roots of violence: Is a South African common good possible? (In Du Toit, C.W., ed. Violence, truth and prophetic silence: Religion and the quest for a South African common good. A compilation of papers presented at the twenty-third symposium of the Research Institute for Theology and Religion (Unisa) held at the University of South Africa. Pretoria. 3-4 June. p. 15-41.)

FLOOR, L. 1990. The Bible on the issue of church and violence. (In Van der Walt, B.J., red. Venster op mag en geweld: Christelike perspektiewe. Potchefstroom: PU vir $\mathrm{CHO}$. Wetenskaplike bydraes van die $\mathrm{PU}$ vir $\mathrm{CHO}$. Reeks F3: Versamelwerke. Nommer 37. p. 55-66.)

HELMICK, R.G. 1999. The role of religion and theology. (In Du Toit, C.W., ed. Violence, truth and prophetic silence: Religion and the quest for a South African common good. A compilation of papers presented at the twentythird symposium of the Research Institute for Theology and Religion (Unisa) held at the University of South Africa. Pretoria. 3-4 June. p. 129143.)

LOUW, M. 2003a. Plaasmoorde 'is etniese uitwissing': SA man, joernalis van VSA stap uit protes teen misdaad. Beeld: 5, Junie 10.

LOUW, M. 2003b. Roof nie rede vir plaasgeweld: Reserviste in plek van kommando's onaanvaarbaar, sê boere. Beeld: 2, Junie 12.

LOUW, M. 2003c. Kommer oor 'peutery' met plaasaanval-verslag. Beeld: 1, Augustus 21.

LOUW, M. 2003d. Stel plaasverslag nóú bekend: staat se erns met aanvalle bevraagteken. Beeld: 4, Aug. 22.

MAYSON, C. 1999. Listening for the prophetic voices: Where have all the prophets gone? (In Du Toit, C.W., ed. Violence, truth and prophetic silence: Religion and the quest for a South African common good. A compilation of papers presented at the twenty-third symposium of the Research Institute for Theology and Religion (Unisa) held at the University of South Africa. Pretoria. 3-4 June. p. 55-81.)

PETERSEN, R.L. 1999. Violence and the church: Tales of hope. (In Du Toit, C.W., ed. Violence, truth and prophetic silence: Religion and the quest for a South African common good. A compilation of papers presented at the twenty-third symposium of the Research Institute for Theology and Religion (Unisa) held at the University of South Africa. Pretoria. 3-4 June. p. 102-128.)

PIETERSE, H.J.C. 1999. Where have all the prophets gone? Prophetic silence and the incapacity of religions to take us forward. (In Du Toit, C.W., ed. Violence, truth and prophetic silence: Religion and the quest for a South African common good. A compilation of papers presented at the twentythird symposium of the Research Institute for Theology and Religion (Unisa) held at the University of South Africa. Pretoria. 3-4 June. p. 82-97.)

REITSEMA, A.H. 1998. Geweld en die Afrika-kultuur. Die Kerkblad: 26-27, September 9.

ROODT, K. 2003. Staat sal bepaal of ons ge-Zim word. Rapport: 3, Maart 30.

SOUTH AFRICA. 1998. Truth and Reconciliation Commission. Report. Houndmills, Basingstroke: Macmillan. 5 Vols. 
SMITH, F.D. 1999. Apartheid and the TRC: An analysis of scapegoat mechanisms in light of the thought of Rene Girard. (In Du Toit, C.W., ed. Violence, truth and prophetic silence: Religion and the quest for a South African common good. A compilation of papers presented at the twentythird symposium of the Research Institute for Theology and Religion TRC (Unisa) held at the University of South Africa. Pretoria. 3-4 June. p. 42-54.) see South Africa, 1998.

TUTU, D.M. 1983. Hope and suffering: Sermons and speeches. Johannesburg: Skotaville.

TUTU, D.M. 1989. Clarifying the Word: A sermon by Desmond Tutu. (In Wallis, J. \& Hollyday, J. Crucible of fire: The church confronts apartheid. Maryknoll: Orbis Books \& Sojourners. p. 33-39.)

VAN NIEKERK, E.A. 1985. Pastoral care in situations of violence. (In Vorster, W.S., ed. Views on violence. Proceedings of the ninth symposium of the Institute for Theological Research (Unisa) held at the University of South Africa. Pretoria. 4-5 September. p. 91-92.)

VAN WYK, J.H. 1991. Kerk, teologie en geweld. (In Van Wyk, J.H. Moraliteit en verantwoordelikheid: Opstelle oor politieke etiek. Potchefstroom: PU vir $\mathrm{CHO}$. Wetenskaplike bydrae van die $\mathrm{PU}$ vir $\mathrm{CHO}$. Reeks A: Geesteswetenskappe. Nr. 77. p. 87-108.)

VILLA-VICENCIO, C. 1990. Revolutionary violence: Towards a theological explanation. (In Van der Walt, B.J., red. Venster op mag en geweld: Christelike perspektiewe. Potchefstroom: PU vir CHO. Wetenskaplike bydraes van die PU vir CHO. Reeks F3: Versamelwerke. Nommer 37, p. 38-54.)

VORSTER, N. 2003. Kerk en menseregte binne 'n regstaat. Potchefstroom: PU vir CHO. (Ph.D.-proefskrif.)

WALLIS, J. \& HOLLYDAY, J. 1989. Crucible of fire: The church confronts apartheid. Maryknoll: Oris Books \& Sojourners.

\section{Key concepts:}

counter violence

liberation struggle

structural violence

violence

\section{Kernbegrippe:}

geweld

strukturele geweld

teengeweld

vryheidstryd 